AGNIESZKA K. CIANCIARA

Instytut Studiów Politycznych PAN

ORCID: 0000-0002-5530-8745

e-mail:agcian@isppan.waw.pl

\title{
Wprowadzenie: Westlessness czyli zmierzch Zachodu 2.0?
}

\author{
Introduction: Westlessness \\ or the decline of the West 2.0?
}

Słowa kluczowe:

Zachód, Unia Europejska, USA, hegemonia, liberalny ład międzynarodowy
Keywords:

West, European Union, USA, hegemony, liberal international order 
Introduction: Westlessness or the decline of the West 2.0?

This article introduces the special section entitled Westlessness or the decline of the West 2.o? Whereas the concept of the West remains a moving target and requires the Other - the Rest to exist and thrive, it does organize both global power relations and the way we think about them. Thus the 'decline of the West' is not only about material realities, but also about de-legitimizing practices and discourses produced by strategically-acting actors both outside and within the West itself. Whereas Westlessness in the World refers to the weakening ability of shaping the Rest, Westlessness in the West denotes contestation and hollowing-out of the liberal rules of the game in the very centre of the West: the US and the European Union. The question remains as to whether Covid-19 pandemic brings "more of the same", while amplifying existing trends, or whether it provides for a transformation impulse and possibly Western revival. 
onachijska Konferencja Bezpieczeństwa (ang. Munich Security Conference: MSC) odbyła się w lutym 2020 roku pod hasłem Westlessness - nowego zmierzchu Zachodu. W przedmowie do konferencyjnego raportu ${ }^{1}$ przewodniczący MSC Wolfgang Ischinger pisał, że „konkretne wyzwania dla bezpieczeństwa stały się nierozłącznie związane z tym, co niektórzy opisują jako rozkład projektu Zachodu: dziś Zachód taki, jakim go znamy, jest kontestowany zarówno od wewnątrz, jak i od zewnątrz. Częścią problemu jest fakt, że utraciliśmy wspólne rozumienie tego, co to znaczy być częścią Zachodu. Wszystko to dzieje się na tle relatywnego wzrostu świata niezachodniego oraz mnożących się wyzwań i kryzysów globalnych, które wymagają zgodnej odpowiedzi ze strony Zachodu"2. Autorzy raportu wskazywali, że pojęcie "Zachód” wymyka się definicjom; stanowi raczej połączenie różnych tradycji, a treść tej mieszanki zmienia się w czasie. Jednak w minionych dekadach tym, co wyróżniało według nich Zachód i utrzymywało jego spoistość, było zaangażowanie na rzecz liberalnej demokracji, praw człowieka, gospodarki rynkowej i międzynarodowej współpracy w ramach multilateralnych instytucji.

W potocznym rozumieniu Zachód to państwa i społeczeństwa ściśle ze sobą powiązane i charakteryzujące się gospodarczą siłą, dominującymi zdolnościami wojskowymi i posiadające znaczną atrakcyjność kulturową. Zachód nie ma przy tym znaczenia geograficznego, jest bowiem zwykle odnoszony zarówno do Europy, Stanów Zjednoczonych Ameryki (USA) i Kanady, jak i do Australii, Nowej Zelandii, a nawet Japonii. O ile imaginarium Zachodu jest historycznie osadzone w Europie Zachodniej, to „idea Zachodu" i powiązane z nią obrazy, praktyki i instytucje „zaczęły żyć własnym życiem"3. Sama geograficzna dyslokacja tworzy możliwość uniwersalizacji Zachodu, jednocześnie jednak idea Zachodu wymaga istnienia Innego. Zachód (the West) wyznacza granice i tworzy różnicę, nabierając znaczenia

1 T. Bunde, R. Carr, S. Eisentraut, Ch. Erber, J. Hammelehle, L. Hartmann, J. Kabus, F. Stark, J. Voje, Munich security report 2020: Westlessness, Munich Security Conference, Munich 2020, dostępny w internecie [dostęp: 16 II 2021]: <https:// securityconference.org/en/publications/munich-security-report-2020/ $>$.

2 Wszystkie cytaty w tłumaczeniu Autorki.

3 Zob. B. Herborth, G. Hellmann, Introduction: Uses of the West, [w:] Uses of the West: Security and the politics of order, eds G. Hellmann, B. Herborth, Cambridge University Press, Cambridge 2017, s. 1. 
tylko w opozycji do niezachodniej Reszty (the Rest) ${ }^{4}$. Zachód byłby zatem czynnikiem organizującym globalne relacje władzy (liberalny porządek międzynarodowy), ale też sposób myślenia i mówienia o nich ${ }^{5}$. Jeśli jednak odejdziemy od esencjalizującego jego rozumienia, zobaczymy, że Zachód (oraz Reszta) nie tylko „jest”, ale jest też na różne sposoby używany - konstruowany i kontestowany - w praktykach i dyskursach politycznych ${ }^{6}$. Owe praktyki i dyskursy mogą być udziałem zarówno tych aktorów, którzy identyfikują się jako część Zachodu, jak i tych, którzy sytuują siebie lub są sytuowani przez Zachód poza nim. Stąd wypada postrzegać dyskursy „zmierzchu" lub „upadku” Zachodu zarówno jako próbę opisu realnie zachodzących i mających materialne podstawy procesów, jak też jako narracje legitymizujące preferencje aktorów, którym ów zmierzch jest na rękę, lub też takich, którzy usiłują mu - w różny sposób - przeciwdziałać.

Autorzy wyżej cytowanego monachijskiego raportu widzą przejawy Westlessness tak na samym Zachodzie (Westlessness in the West), jak i poza nim (Westlessness in the World). Z perspektywy stosunków międzynarodowych w obu przypadkach u źródeł zmierzchu Zachodu (rozumianego jako „wspólnota transatlantycka”) leży pogłębiający się rozziew między Europą ${ }^{7}$ a Stanami Zjednoczonymi, jeśli idzie o postrzeganie szans i zagrożeń, pożądaną wizję porządku światowego i metody realizacji tej wizji. Fundamentalne różnice ujawniły się już na początku XXI wieku w kontekście amerykańskiej inwazji na Irak i jej jednoznacznej krytyki ze strony części europejskich sojuszników. Jak pisał w 2003 roku Robert Kagan, „czas przestać udawać, że Europejczycy i Amerykanie mają wspólną wizję świata albo że żyją $\mathrm{w}$ tym samym świecie"s. Jednak rosnący rozziew zamienił się - $\mathrm{w}$ opinii części komentatorów - w przepaść wraz z prezydenturą Donalda Trumpa

4 S. Hall, The West and the Rest. Discourse and power, [w:] Formations of modernity, eds S. Hall, B. Gieben, Polity Press, Cambridge 1992, s. 275-320.

5 S. Hall, The West and the Rest, s. 278.

6 B. Herborth, G. Hellmann, Introduction: Uses of the West, s. 4. Por. I. B. Neumann, Self and other in international relations, "European Journal of International Relations" 1996, no. 2(2), s. 139-174.

7 Jest to oczywiste uproszczenie: podziały w łonie wspólnoty transatlantyckiej i samej Unii Europejskiej są daleko bardziej skomplikowane.

8 R. Kagan, Of paradise and power. America and Europe in the new world order, Alfred A. Knopf, New York 2003, s. 3. 
(2016-2020). W tej optyce Zachód stał się bardziej podzielony, globalne interesy strategiczne ulegały coraz głębszemu zróżnicowaniu, a działania amerykańskiego prezydenta (takie jak wycofanie USA z paryskiego porozumienia klimatycznego czy porozumienia nuklearnego z Iranem) znacznie obniżyły poziom zaufania $w$ relacjach transatlantyckich ${ }^{9}$. Nie jest przesądzone, czy i w jakim stopniu zmiana administracji w Waszyngtonie, jaka dokonała się na początku 2021 roku, odwróci tak rozumiany trend.

Westlessness in the World wyraża się w słabnącej zdolności zachodnich potęg do kształtowania otoczenia zewnętrznego, tj. umacniania i ekspansji liberalnego ładu międzynarodowego ${ }^{10}$. Proliferacja lokalnych i regionalnych konfliktów w ciągu ostatniej dekady (Libia, Syria, Ukraina, Górski Karabach) świadczy o próbach wykorzystania postrzeganych słabości Zachodu przez lokalnych i regionalnych liderów poszukujących nowych szans wzmocnienia swojej pozycji $\mathrm{w}$ obliczu postępującej transformacji systemu międzynarodowego. Jak zauważył minister spraw zagranicznych Niemiec Heiko Maas, przyszłość Bliskiego Wschodu nie decyduje się już w Genewie czy Nowym Jorku, ale w Astanie i Soczi, gdzie spotykają się przywódcy Rosji, Turcji i Iranu. Przyczyną tego stanu rzeczy miałoby być pozostawienie "geostrategicznych luk" przez wycofujące się Stany Zjednoczone i wypełnianie ich przez aktorów niepodzielających zachodnich wartości ${ }^{11}$. Zwrot $w$ kierunku strategii defensywnych i obrony status quo jest dobrze widoczny w polityce zagranicznej Unii Europejskiej i przejawia się chociażby w retorycznym uprzywilejowaniu tzw. odporności (ang. resilience) kosztem deklarowanej wcześniej transformacji i europeizacji unijnego sąsiedztwa ${ }^{12}$.

9 Por. V.Tcherneva, The end of the concept of the 'West'?, ECFR Commentary, 18 V 2018 [dostęp: 24 II 2021], dostępny w internecie: <https://ecfreu/article/ commentary_the_end_of_the_concept_of_the_west/>.

10 Por. G. J. Ikenberry, Liberal internationalism 3.0. America and the dilemmas of the liberal world order, "Perspectives on Politics" 2009, no. 7(1), s. 71-87.

11 Zob. P. Wintour, 'Westlessness': is the West really in the state of peril?, "The Guardian" [online], 16 II 2020 [dostęp: 23 III 2021], dostępny w internecie: <https://www.theguardian.com/world/2020/feb/16/westlessness-is-the-west-really-in-a-state-of-peril $\rangle$.

12 Zob. S. Blockmans, The Eastern Partnership at 10. The road to hell is paved with good intentions, "CEPS In Brief", O6 V 2019 [dostęp: 02 IV 2021], dostępny w internecie: $\langle$ https://www.ceps.eu/the-eastern-partnership-at-10/>; A. K. Cianciara, The politics of the European neighbourhood policy, Routledge, London-New York 2020, s. 166. 
Według prezydenta Francji Emmanuela Macrona „jesteśmy bez wątpienia świadkami końca zachodniej hegemonii w świecie" ${ }^{\text {"13 }}$. W rezultacie ład międzynarodowy, opierający się od osiemnastego wieku na dominacji Zachodu, uległ bezprecedensowemu zachwianiu oraz postępującej transformacji geopolitycznej i strategicznej. W opinii francuskiego prezydenta zmiany te wynikają z błędów samego Zachodu, w tym Stanów Zjednoczonych, oraz nazbyt długotrwałego niedoceniania przez Zachód strategii nowych potęg, zwłaszcza Chin i Rosji. Perspektywa strategicznej konwergencji obu tych graczy prowadzi część zachodnich decydentów, w tym francuskiego prezydenta, do wniosku o konieczności „odzyskania” Rosji dla Zachodu w celu ograniczenia geopolitycznych strat ${ }^{14}$. Wydaje się jednak, że wielu zachodnich obserwatorów wyolbrzymia zarówno negatywne konsekwencje rosyjsko-chińskiej współpracy (a nie sojuszu) dla Europy i USA, jak i zdolność Zachodu do osłabienia relacji, której asymetryczny charakter nie tylko nie stanowi zagrożenia dla przetrwania rosyjskiego reżimu, ale wręcz tworzy nowe możliwości ekstrakcji renty dla rosyjskiej elity władzy. Choć tak Chiny, jak i Rosja kontestują reguły gry liberalnego ładu międzynarodowego, to posiadają odmienne oczekiwania co do kształtu nowego ładu oraz różne narzędzia jego kształtowania. Na przykład polityka regionalnej destabilizacji, będąca głównym narzędziem stosowanym przez Rosję, stanowi bezpośrednie zagrożenie dla gospodarczej ekspansji Chin ${ }^{15}$.

Jednak kontestacja zachodnich (liberalnych) reguł gry prowadzona jest nie tylko z zewnątrz, ale i - co dużo istotniejsze - od wewnątrz, zarówno przez opinię publiczną (i niekiedy rządy) w państwach, które przywykliśmy uważać za centrum liberalnego Zachodu, jak i przez opinię publiczną oraz rządy w państwach, które do Zachodu dołączyły (lub tylko aspirowały) stosunkowo niedawno, i postrzegane są, oraz postrzegają siebie, jako jego (pół) peryferie (wewnętrzne i/lub zewnętrzne - granica jest tu płynna). Źródeł owej kontestacji należy upatrywać nie tylko w sferze materialnej, w związku

13 Discours du Président de la République Emmanuel Macron à la Conférence des Ambassadeurs et des Ambassadrices de 2019, Elysée, 27 VIII 2019 [dostęp: O2 IV 2021], dostępny w internecie: 〈https://www.elysee.fr/front/pdf/elysee-module-14146-fr.pdf>.

14 M. Kaczmarski, The Sino-Russian relationship and the West, "Survival: Global Politics and Strategy" 2020, no. 62(6), s. 199, DOI: 10.1080/00396338.2020.1851101.

15 M. Kaczmarski, The Sino-Russian relationship..., s. 206-207. 
z kurczeniem się gospodarczej dominacji (przewagi) Zachodu, ale również, a może przede wszystkim, w politycznie mobilizowanej frustracji, wynikającej z zagrożonej lub podrzędnej pozycji w porządku uznania (ang. recoğnition order), tworzonym i podtrzymywanym przez liberalny ład międzynarodowy ${ }^{16}$. Konsekwencją owej frustracji są sukcesy sił populistycznych odnoszone tak w centrum, jak i na peryferiach Zachodu. Badania pokazują, że poparcie dla populistów jest związane nie tyle z trudną sytuacją ekonomiczną ich wyborców, co raczej z obawami o utratę statusu społecznego (w wymiarze indywidualnym, grupowym, państwowym) na rzecz dotychczasowych grup mniejszościowych lub - w przypadku (pół)peryferii - z niezdolnością do uzyskania wyższego (a postrzeganego jako należny) statusu, i to pomimo znacznego wysiłku adaptacyjnego włożonego w "dołączenie do Zachodu” (ang. catching-up with the West) i przestrzeganie obowiązujących w nim regul gry ${ }^{17}$.

Kontestacja (liberalnego) Zachodu na Zachodzie (Westlessness in the West) jest napędzana przez charakterystyczną dla backlash politics ${ }^{18}$ retrotopię ${ }^{19}$, zwróconą nie ku postępowi i przyszłości, ale ku mitologizowanej przeszłości, stanowiącej jakoby szansę na uratowanie upadającej kultury Zachodu $^{20}$, rozumianej w duchu zgoła spenglerowskim. Zdaniem Oswalda Spenglera ${ }^{21}$ Zachód przeszedł od kultury duchowej (stadium wzrostu) do cywilizacji świeckiej, materialnej, praktycznej (stadium zmierzchu) ok. 1800 roku $^{22}$. Charakterystyczna dla cywilizacji jest dominacja

16 R. Adler-Nissen, A. Zarakol, Struggles for recognition. The liberal international order and the merger of its discontents, "International Organization" 2020, s. 2, DOI:10.1017/ Soo20818320000454.

17 R. Adler-Nissen, A. Zarakol, Struggles for recognition, s. 8 i 11.

18 K. J. Alter, M.Zuern, Conceptualising backlash politics. Introduction to a special issue on backlash politics in comparison, "The British Journal of Politics and International Relations" 2020, no. 22(4), s. 739-752, DoI: 10.1177/1369148120947956.

19 Z. Bauman, Retrotopia: jak rządzi nami przeszłość?, Wydawnictwo Naukowe PWN, Warszawa 2018.

20 Por. W. Roszkowski, Roztrzaskane lustro. Upadek cywilizacji zachodniej, Biały Kruk, Kraków 2019.

21 O. Spengler, Zmierzch Zachodu. Zarys morfologii historii powszechnej, przeł. J. Marzęcki, Wydawnictwo Aletheia, Warszawa 2014.

22 Zob. Z. Bauman, A. Kania, That West meant to be declining, "Thesis Eleven" 2018, 149(1), s. 95, dostępny w internecie [dostęp: 23 III 2021]: <https://journals.sagepub. com/doi/full/10.1177/o725513618811722>. 
władzy pieniądza, jak również areligijność bądź religijność zracjonalizowana, w której instynkt i obyczaje zostały zastąpione abstrakcyjnymi rozważaniami, intelektualizmem i sceptycyzmem. Moralność ma dostarczać reguł postępowania ludziom, których życie stało się problematyczne, pełne wahań i rozterek. Zamiast tragicznej postawy wymagającej stawiania czoła losowi - typowej dla człowieka kultury - pojawia się moralność wielkomiejskiej masy ludzkiej, szukającej ucieczki przed przeznaczeniem i zmaganiem się z nim. Przejawami cywilizacji, a więc zmierzchu Zachodu, są według Spenglera wszelkie formy demokracji: parlamentaryzm, liberalizm, partie polityczne, które jako organizacje zastąpiły to, co organiczne, naturalne - stany. Wszystko to jest następstwem zaniku właściwych kulturze napięć, odchodzenia od wartości „życia”, czego jedynym skutkiem może być śmierć, poprzedzona starzeniem się ${ }^{23}$. W takiej optyce „renesans Zachodu”, jeśli w ogóle jest jeszcze możliwy, musi być z konieczności antyliberalny.

Być może zamiast o zmierzchu Zachodu powinniśmy mówić o jego transformacji. Jakie są jej możliwe kierunki poza rozpaczliwą obroną status quo? Czy Zachód miałby wrócić do swych chrześcijańskich i przedoświeceniowych korzeni? Czy będzie musiał stać się taki jak „Wschód”, by przetrwać? A może szansą dla Zachodu jest pełna realizacja progresywnych i emancypacyjnych obietnic, których nigdy nie dotrzymał? Jak to uczynić w warunkach coraz ostrzejszej konkurencji ze strony niezachodniej „Reszty” oraz w warunkach pandemii, która przeorała zachodnie gospodarki i społeczeństwa? Czy długofalowe konsekwencje pandemii to "więcej tego samego" czy może stanie się ona kołem zamachowym wielkiej społeczno-gospodarczej transformacji na podobieństwo czarnej śmierci z połowy XIV wieku, która w długim okresie przyniosła Europejczykom fundamentalną zmianę modelu rozwojowego i pośrednio umożliwiła globalną ekspansję ${ }^{24}$ ? A może nowa „zimna wojna” z Chinami - implikująca konstrukcję jasno określonego i wspólnego dla Zachodu zagrożenia w wymiarze gospodarczym,

23 Zob. A. Kołakowski, Spengler, Wiedza Powszechna, Warszawa 1981; G. Szumera, Historiozofia Oswalda Spenglera a koncepcja filozoficzna Erazma Majewskiego, „Folia Philosophica" 1993, nr 11, s. 89-93.

24 Zob. R. Jedwab, N. D. Johnson, M. Koyama, The economic impact of the black death, "Journal of Economic Literature", American Economic Association, forthcoming in 2021. 
militarnym, politycznym i aksjologicznym - stanowi szansę na konsolidację i odnowę liberalnego ładu międzynarodowego ${ }^{25}$ ?

Teksty zawarte w niniejszym tomie powstawały w połowie 2020 roku: już w obliczu pierwszej fali pandemii covID-19, ale jeszcze bez znajomości wyniku wyborów prezydenckich w USA z listopada 2020. Stanowią one interesujące świadectwo interregnum: czasu, kiedy już wiemy, że dotychczasowe instytucje i sposoby działania wyczerpały się, ale nowe jeszcze nie powstały. Gra toczy się o to, kto będzie definiował ich kształt.

Pytanie o to, czy pandemia CovID-19 stanowi katalizator upadku Zachodu, stawiają Przemysław Mikiewicz i Andrzej Polus. Problem ten rozważany jest w kontekście kryzysu oświeceniowego modelu tworzenia wiedzy i zinstytucjonalizowanej nauki, które stanowiły fundament nowożytnej dominacji Zachodu. Przyjmując perspektywę konstruktywistyczną, autorzy analizują procesy związane ze znaczeniem intersubiektywnej wiedzy dla hegemonii Zachodu oraz diagnozują przemiany, jakie dokonują się pod wpływem pandemii w świecie zdominowanym dotąd przez zachodni racjonalizm i związany z nim system produkcji i weryfikacji wiedzy. Kryzys zaufania do wiedzy naukowej, prowadzący do erozji intelektualnych fundamentów Zachodu, jest ściśle związany z kryzysem legitymizacji instytucji międzynarodowych, rozumianych jako narzędzia służące dostarczaniu opartych na wiedzy rozwiązań kolektywnych problemów o zasięgu międzynarodowym. Owa „ucieczka od rozumu” implikuje "tragedię wspólnego pastwiska” - preferowanie działań unilateralnych i doraźnych kosztem regulacji tworzących systemowe rozwiązania korzystne dla możliwie największej liczby graczy.

Czy Zachód przegrał pandemię? Katarzyna Pisarska dowodzi, że krajowe i międzynarodowe strategie radzenia sobie z pierwszą falą pandemii będą miały trwałe konsekwencje dla zdolności państw do projektowania miękkiej siły (ang. soft power) na arenie międzynarodowej. $\mathrm{O}$ ile w pierwszej połowie 2020 roku Niemcy i Korea Południowa zwiększyły swoje zasoby miękkiej siły, o tyle zarówno w przypadku USA, jak i Chin zasoby te uległy zmniejszeniu. Pomimo szybkiego zduszenia pandemii w kraju i aktywnej „dyplomacji maseczkowej" Chiny nie zdołały wykorzystać kryzysu do poprawy międzynarodowego postrzegania ich polityki zagranicznej. Autorka zwraca uwagę, że zmienne, takie jak system polityczny (demokratyczny v. niedemokratyczny)

25 Zob. D. Tierney, Why global order needs disorder, "Survival: Global Politics and Strategy" 2021, no. 63(2), s. 115-116, DOI: 10.1080/00396338.2021.1905981. 
czy wcześniejsze doświadczenie w zarządzaniu pandemią (państwa azjatyckie v. państwa zachodnie) mają niską moc eksplanacyjną, natomiast kluczowe znaczenie należy przypisywać instytucjonalnie zakorzenionej kulturze współpracy, zaufaniu społecznemu oraz jakości przywództwa.

Jakie są materialne przesłanki „zmierzchu Zachodu”? Analizując szereg wskaźników gospodarczych $\mathrm{w}$ odniesieniu m.in. do USA, UE i Chin, Lech Smolaga i Mateusz Smolaga poszukują odpowiedzi na pytanie o polityczne konsekwencje zmian w gospodarce światowej dla ładu międzynarodowego. Ekstrapolacja aktualnych trendów wskazuje na dalsze osłabianie potencjału gospodarczego UE i USA oraz wzmacnianie potencjału Chin, co w perspektywie 2030 roku będzie prowadzić do utraty przewag komparatywnych Zachodu, które decydowały o jego dominacji. Układ sił między wspominanymi trzema graczami będzie - zdaniem autorów - w znacznej mierze determinowany zdolnością Unii Europejskiej do odbudowy i transformacji gospodarki po pandemii.

Kondycja Unii Europejskiej, jednego z dwóch najważniejszych filarów Zachodu, jest przedmiotem refleksji autorów dwóch kolejnych tekstów. Ewa Suwara analizuje konsekwencje wystąpienia z Unii państwa członkowskiego - pierwszego w historii integracji europejskiej - dla współpracy w dziedzinie polityki zagranicznej, bezpieczeństwa i obrony na kontynencie europejskim. Zakończenie z dniem 31 grudnia 2020 roku okresu przejściowego bez wynegocjowania porozumienia $\mathrm{w}$ tym obszarze nie przekreśla perspektyw współpracy państw członkowskich UE i Zjednoczonego Królestwa, $\mathrm{w}$ tym $\mathrm{w}$ ramach innych organizacji międzynarodowych. Osłabia jednak potencjał militarny i polityczny Unii na arenie międzynarodowej.

Z kolei Natalia Szulc i Adam Szymaniak przyğlądają się praktykom eksterytorializacji w zakresie kontroli migracji i polityki azylowej Unii Europejskiej. Posługując się pojęciem komercjalizacji odpowiedzialności, analizują konsekwencje delegowania odpowiedzialności do państw trzecich na przykładzie porozumień zawartych przez UE z Libią i Turcją. Taka delegacja spełnia kryterium „efektywności” działania, tj. pozwala zmniejszyć liczbę migrantów przybywających do Europy i jednocześnie unikać odpowiedzialności za łamanie praw człowieka i kryzysy humanitarne w ośrodkach detencyjnych rozmieszczonych poza granicami Unii. $\mathrm{W}$ opinii autorów komercjalizacja odpowiedzialności podważa aksjologiczne fundamenty Unii Europejskiej osadzone w zachodniej doktrynie praw człowieka i prawie międzynarodowym. 
W numerze znalazły się również teksty, które nie odnoszą się bezpośrednio do zagadnienia zmierzchu Zachodu, niemniej podejmują różne szczegółowe wątki dotyczące aktualnych przemian w polityce międzynarodowej, w tym układu sił w Azji Wschodniej, efektywności misji cywilno-wojskowych NATO oraz paradyplomacji jako ważnego narzędzia polityki zagranicznej państwa.

Jakie są geopolityczne uwarunkowania polityki Chin wobec Korei Północnej? Paweł Bielicki analizuje takie czynniki jak: wojna handlowa między Chinami i USA, pogorszenie relacji z sojusznikami USA w Azji Wschodniej - Koreą Południową i Japonią, jak również podjęcie przez Koreę Północną dialogu z USA. Zwraca uwagę na ograniczenia, jakie dla chińskiej polityki wynikają z możliwości balansowania przez KRLD między Chinami, USA, Koreą Południową i Rosją.

Z kolei Agata Mazurkiewicz bada konflikt roli wpisany w funkcjonowanie żołnierzy zajmujących się współpracą cywilno-wojskową w ramach NATo. Konflikt między tożsamością wojownika a tożsamością strażnika pokoju może mieć - zdaniem autorki - realne konsekwencje dla zdolności osiągania wyznaczonych celów w obszarze misji wojskowych oraz efektywnego współdziałania z aktorami cywilnymi. Złożony kontekst współczesnego zaangażowania militarnego wymaga zintegrowanego podejścia do operacji pokojowych, implikując ścisłą współpracę podmiotów cywilnych i wojskowych, z czym wiążą się sprzeczne normatywne oczekiwania wobec żołnierzy ze strony sił zbrojnych z jednej i partnerów cywilnych z drugiej strony. Implementacja praktycznych wniosków wynikających $\mathrm{z}$ analizy konfliktu roli może przyczynić się do wzrostu efektywności misji natowskich oraz wzmocnienia legitymizacji tej organizacji.

Analizując instytucjonalny wymiar polskiej paradyplomacji, Igor Ksenicz podejmuje refleksję nad pożądanym, z perspektywy polityki zagranicznej RP, modelem dyplomacji samorządowej. Autor argumentuje, że faktyczna rezygnacja przez Ministerstwo Spraw Zagranicznych z wymiaru samorządowego i obywatelskiego polityki zagranicznej RP po zmianie rządu w 2015 roku negatywnie wpływa na rozwój polskiej paradyplomacji, tym samym pozbawiając Polskę ważnych narzędzi realizacji polityki zağranicznej.

Dopełnienie numeru stanowią dwa artykuły recenzyjne. Pierwszy z nich, autorstwa Stanisława Czesława Kozłowskiego, stanowi omówienie pracy zbiorowej pod redakcją zmarłego w marcu 2021 roku wybitnego polskiego sinologa Krzysztofa Gawlikowskiego i jego współpracowników, przybliżającej 
polskiemu czytelnikowi przemiany społeczne i kulturowe w Państwie Środka w świetle wybranych tytułów prasy chińskiej ostatnich dwóch dekad. Analiza prasy ukazuje dylematy związane z modernizacją Chin w zderzeniu z konfucjańską tradycją, „wielkim odrodzeniem narodu chińskiego", budową "demokracji konsultatywnej” oraz "nowego modelu stosunków międzynarodowych”. W książce przedstawiono również problematykę związaną z przemianami struktury społecznej, w tym relacji miasto - wieś, pracownik - pracodawca, obywatel - władza, jak również z ewolucją obyczajowości czy rolą mediów.

W drugim artykule recenzyjnym Ryszard Żelichowski omawia pracę niderlandzkiego autora Duco Hellemy pt. The global 1970s (Routledge 2018). Książka stanowi próbę spojrzenia na "długą dekadę" z perspektywy globalnej i uchwycenia początkowego reformatorskiego zapału, konsekwencji kryzysu naftowego i alternatyw wobec wolnego rynku, ewolucji sytuacji w bloku komunistycznym i roli świata niezachodniego. Autor recenzji zwraca uwage, że na skutek kryzysu gospodarczego lat 70 . XX wieku globalna dominacja Zachodu uległa osłabieniu, jednak już w połowie lat 8o. została na powrót wzmocniona. Omawiana dekada to w świecie zachodnim czas wyczerpywania się społeczno-gospodarczego modelu opartego na interwencjonizmie, a także czas rosnącego indywidualizmu, społecznych niepokojów, lewicowego idealizmu i radykalizmu, ale i politycznego ekstremizmu i terroru. Atmosfera pesymizmu, przeczucie "końca postępu” i zapowiedzi konserwatywnej kontrrewolucji mogą wydać się czytelnikowi dziwnie bliskie.

\section{Bibliografia}

Adler-Nissen R., Zarakol A., Struggiles for recognition: The Liberal International Order and the Merger of Its Discontents, "International Organization" 2020, DOI:10.1017/ Soo20818320000454.

Alter K. J., Zuern M., Conceptualising backlash politics: Introduction to a special issue on backlash politics in comparison, "The British Journal of Politics and International Relations" 2020, no. 22(4), s. 739-752, DOI: 10.1177/1369148120947956.

Bauman Z., Kania A., That West meant to be declining, "Thesis Eleven" 2018, 149(1), dostępny w internecie [dostęp: 23 III 2021]: <https://journals.sagepub.com/doi/ full/10.1177/o725513618811722>.

Bauman Z., Retrotopia: jak rządzi nami przeszłość?, Wydawnictwo Naukowe PWN, Warszawa 2018.

Blockmans S., The Eastern Partnership at 10. The road to hell is paved with good intentions, "CEPS In Brief", o6 V 2019 [dostęp: 02 IV 2021], dostępny w internecie: $\langle$ https://www.ceps.eu/the-eastern-partnership-at-10/>. 
Bunde T. et al., Munich security report 2020: Westlessness, Munich Security Conference, Munich 2020, dostępny w internecie [dostęp: 16 II 2021]: 〈https://securityconference.org/en/publications/munich-security-report-2020/ $>$.

Cianciara A. K., The politics of the European neighbourhood policy, Routledge, London-New York 2020.

Discours du Président de la République Emmanuel Macron à la Conférence des Ambassadeurs et des Ambassadrices de 2019, Elysée, 27 VIII 2019, dostępny w internecie [dostęp: 02 IV 2021]: <https://www.elysee.fr/front/pdf/elysee-module-14146-fr.pdf $>$.

Hall S., The West and the Rest. Discourse and power, [w:] Formations of modernity, eds S. Hall, B. Gieben, Polity Press/Open University Cambridge 1992.

Herborth B., Hellmann G., Introduction: Uses of the West, [w:] Uses of the West. Security and the politics of order, eds G. Hellmann, B. Herborth, Cambridge University Press, Cambridge 2017.

Ikenberry G. J., Liberal internationalism 3.0. America and the dilemmas of the liberal world order, "Perspectives on Politics" 2009, no. 7(1), 71-87.

Jedwab R., Johnson N. D., Koyama M., The economic impact of the black death, "Journal of Economic Literature", American Economic Association, forthcoming in 2021.

Kaczmarski M., The Sino-Russian relationship and the West, "Survival: Global Politics and Strategy" 2020, no. 62(6), DOI: 10.1080/00396338.2020.1851101.

Kagan R., Of paradise and power: America and Europe in the new world order, Alfred A. Knopf, New York 2003.

Kołakowski A., Spengler, Wiedza Powszechna, Warszawa 1981.

Neumann I. B., Self and other in international relations, "European Journal of International Relations" 1996, no. 2(2), s. 139-174.

Roszkowski W., Roztrzaskane lustro. Upadek cywilizacji zachodniej, Biały Kruk, Kraków 2019.

Spengler O., Zmierzch Zachodu. Zarys morfologii historii powszechnej, przeł. J. Marzęcki, Wydawnictwo Aletheia, Warszawa 2014.

Szumera G., Historiozofia Oswalda Spenglera a koncepcja filozoficzna Erazma Majewskiego, „Folia Philosophica” 1993, nr 11.

Tcherneva V., The end of the concept of the 'West'?, ECFR Commentary, 18 V 2018, [dostęp: 24 II 2021], dostępny w internecie: <https://ecfr.eu/article/commentary_the_end_of_the_concept_of_the_west/ $\rangle$.

Tierney D., Why global order needs disorder, "Survival: Global Politics and Strategy" 2021, nr 63(2), DOI: 10.1080/00396338.2021.1905981.

Wintour P., 'Westlessness': is the West really in the state of peril?, “The Guardian” [online], 16 II 2020 [dostęp: 23 III 2021], dostępny w internecie: <https://www.theguardian. com/world/2020/feb/16/westlessness-is-the-west-really-in-a-state-of-peril $>$. 